\title{
Biochar: An Ingredient to Redress Stubble Burning and Boost Crop Production
}

\author{
J. Jyothsna* \\ Department of Horticulture, Jawaharlal Nehru Krishi Vishwa Vidhyalaya, \\ Jabalpur, Madhya Pradesh-482004, India \\ *Corresponding author
}

\section{Keywords}

Stubble burning, Agricultural residue, Biochar, GHG's emission and mitigation

Article Info

Accepted:

04 November 2019

Available Online:

10 December 2019

\section{A B S T R A C T}

\section{Introduction}

India is the second-largest agro-based economy wherein crop cultivation is taken all around the year, producing a large amount of agricultural waste, including the crop residue otherwise the stubbles. The prime means of disposing of the stubbles, in North India, is being the stubble burning that has popped out as a major issue of environment issue, severely affecting the air quality of the Delhi NCR, since 2015. This steers to serious health threats and ultimately global warming. Though the GOI had sought to restrict this problem through various measures and campaigns to promote sustainable stubble management, the issue is not yet under control rather alarming rise in air pollution added by the stubble burning is the only result.

The agricultural crop residue is the plant material left-back in the field after a machine harvest. In normal Indian conditions where there are three crops taken in a year, farmers find less or no time to prepare their field for the next crop and a lack of suitable economically efficient technology to dispose of stubbles make them tend to burn stubbles as it is a rapid easy way to clear the field. The exasperating fact is the existence of 
misconceptions about the stubble burning like it enhances soil fertility, helps weed, pest and disease control, encourage farmers to burn stubbles more. Annually India produces about $500 \mathrm{Mt}$ of crop residue of which $60 \mathrm{Mt}$ in Uttar Pradesh, 51 Mt in Punjab and $46 \mathrm{Mt}$ in Maharashtra are burnt on-farm for field preparation (Jain et al., 2014). Generally, the stubbles of the wheat crop are burnt to prepare the field for Rabi crop, from Mid-October to November.

Since the 1980s, the smoke plumes from Punjab reach the Delhi NCR at the onset of November - December, when harvest begins in Punjab and Haryana. Punjab lies directly in the path of North Easterly wind that blows throughout the winter over North India. This Westerly wind brings the polluted air mass from the western parts into Indo-Gangetic plains, which is already polluted by various anthropogenic activities. The pollution in the air quality escalates as the dispersion of smoke plumes is decreased by the low temperature of the winter, thus victimizing Delhi NCR.

\section{Root cause of stubble burning}

Agreeing Prof. M.S. Swaminathan's dissonance on blaming the farmers alone for this issue, many causes and facts in the background that have sown the germ for farmers' stubble burning practice have to be deliberated. The mechanization of rice and wheat harvest, due to lack of labor availability, leaves one-foot tall stubbles in the field, is the prime point from where the crop stubbles come into existence. The reason for stubble burning from the farmers' side is the difficulty in collecting and disposing of the crop residue in a very limited time between two consecutive crops, perhaps a slight delay in sowing of Rabi crop brings a drastic impact on economic returns. It is obvious that the incidence of stubble burning has higher frequency during the post-harvest period of
April-May and November-December (Jitendra et al., 2017). Rice cv. Pusa Basmati 1509 that matures in 120 days is predominantly grown during the Rabi season in the rice growing regions of Punjab and Haryana. A little delay in the sowing date will deprive the crop of favorable temperature during flowering resulting in the prolonged crop duration of 160 days, thus affecting economic returns. Shockingly the limited time gap between two consecutive crops was brought into being by two identical acts passed by the State Governments of Punjab and Haryana namely 'Preservation of Subsoil Water Act, 2009', which was efficient enough to pose a restriction on farmers to alter the cropping pattern. To reduce the withdrawal of groundwater for the summer crop, this Act mandated the farmers not to take up summer crop during April-May, but recommended to sow onwards July, when the monsoon onsets. Thus a delay in sowing, so is a delay in harvest, leading to a short period in between for land preparation for the next crop.

The State, as well as Central Government, had taken efforts for stubble management by providing farmers with various equipments namely Choppers, Happy Seeder, Super straw management system (Super-SMS) and Rotovator. However, they didn't gain any prominent acceptance among farmers as their operation require tractors with high basic horsepower (70-80 BHP), while commonly used tractors are of 30-60 BHP.

The states Punjab and Haryana are very well irrigated states, where the electricity and water are available for the farmers at free of cost. Thus, the farmers are convinced as well as compelled to produce rice throughout the year with an altered cropping pattern due to the subsidies and incentives; abundant availability of electricity and water; and the Government Acts and assured procure of produce by FCI for export markets. 


\section{Outcomes of stubble burning}

The burning of stubbles causes various ill effects that are deleterious to human health, soil health, soil-dwelling organisms, ecosystem, and environment. The smoke plumes from stubble burning carry fine black carbon particles that remain entrained in wind for vast distances. The black carbon particles are referred to as soot that is a subset of particulate matter (PM 2.5) and on inhaling causes serious health threats in humans (Sarkar et al., 2018). It is reported that the burning of one tonne of rice straw accounts for a loss of $5.5 \mathrm{Kg}$ nitrogen, $2.3 \mathrm{Kg}$ phosphorous, $25 \mathrm{Kg}$ potassium and $1.2 \mathrm{Kg}$ Sulphur in addition to organic carbon thus reducing soil fertility (NPMCR, 2014). Moreover, the humus formed in the top layer is destroyed by stubble burning, through which we deprive ourselves of good natural manure.

The heat produced from burning is lethal to beneficial soil organisms such as nitrogen and phosphorous fixing PGPRs and earthworms leading to a reduction in the levels of soil nitrogen and carbon in the topsoil that supports the plant root growth. Lack of fodder availability is one of the issues generated by the stubble burning. Furthermore, it also causes disturbances to the crop friendly insects, rodents, birds and other animals, thereby it brings a perturbation in the food cycle on which humans stand on top.

The principal adverse effect of stubble burning on the environment is the emission of greenhouse gases (GHG's) and raised levels of particulate matter (PM) that engender global warming and loss of biodiversity of agricultural lands. Burning of crop residues releases increased quantity of air pollutants viz., $\mathrm{CO}_{2}, \mathrm{CO}, \mathrm{NH}_{3}, \mathrm{NO}_{\mathrm{x}}, \mathrm{SO}_{\mathrm{x}}$, Non-methane hydrocarbon (NMHC), volatile organic compounds (VOCs), semi-volatile organic compounds (SVOCs) and particulate matter
(PM) into the atmosphere (Bhuvaneshwari et al., 2019). Therefore, stubble burning is one such an anthropogenic activity giving rise to GHG's that is essentially need to be curbed. The total GHG's emission by the stubble burning was around $5676.46 \mathrm{Kg}_{\text {year }}{ }^{-1}$, out of which $\mathrm{CO}, \mathrm{CH}_{4}$ and $\mathrm{N}_{2} \mathrm{O}$ contributed for $5666.1 \mathrm{~kg}$ year $^{-1}, 10.10 \mathrm{~kg}$ year $^{-1}$ and0.26 kg year $^{-1}$, respectively (Satyendra, 2015).

\section{The November trouble}

As of the get-go of November 2019, as usual as every year, the farm fires came into notice as placards of the harvest season, worsening Delhi's air quality. The already riddled Delhi's air quality by coal mining, fossil fuel combustion, industrial sources, vehicular traffic, and the growing population was further fouled by smoke plumes of stubble burning, arriving from Western parts of India. This condition was aggravated by the lowered wind speed due to Western disturbance and lowered temperature. As per the data of NASA compiled by the Council of Energy, Environment and Water (CEEW), New Delhi, an astronomical increase in stubble burning was noticed within the term of three days. On $7^{\text {th }}$ November the number of farm fire events was 151 while that on $10^{\text {th }}$ November was 2289, which is an inconceivable increase of 1415.89 per cent. The average number of farm fires over this post-harvest season was recorded as 1623 fires day ${ }^{-1}$.

Consequently the air quality index (AQI) of Delhi, as manifested by the System of Air Quality and Weather Forecasting and Research (SAFAR), Pune, was put into the category 'severe', with PM 10 of $612 \mu \mathrm{g} \mathrm{m}^{-3}$ and PM 2.5 of $393 \mu \mathrm{g} \mathrm{m}^{-3}$ (as on $15^{\text {th }}$ November, 2019), against 100 and $60 \mu \mathrm{g} \mathrm{m}^{-3}$ respectively, to be in the category 'satisfactory'. The number of farm fires on $5^{\text {th }}$ November $(4,824)$ explains the dramatic dip in Delhi's air quality. Moreover, SAFAR had 
forecasted an improvement in Delhi's AQI to the category 'very poor' after $18^{\text {th }}$ November only, which needs to be monitored further.

\section{Biochar - A panacea for stubble burning}

Biochar can serve as a potential ingredient to remediate the problem caused by the stubble burning. There are many reports available presenting the scope of biochar in improving soil nutrient status, plant productivity and mitigation of greenhouse gases and are discussed in this section.

Biochar is a charred, organic, solid, porous, fine-grained, carbon-rich product obtained from the thermochemical conversion, called pyrolysis, under the condition of low or no oxygen (Amonette et al., 2009; Liu et al., 2014).It is a material of comparably higher carbon content than that of its parent material, high stability and surface area of $0.5-450 \mathrm{~m}^{2} \mathrm{~g}^{-}$ 1 (Brassard et al., 2016). It is reported to contain nutrients such as phosphorus, potassium, calcium and magnesium; and micronutrients namely copper, iron, manganese and zinc (Cheng et al., 2008). The carbon, nitrogen content and the carbonnitrogen ratio of biochar ranged from 33.0 to 82.7 per cent, 0.10 to 6.0 per cent and 19 to 221, respectively (Jha et al., 2010; Spokas et al., 2010). The biochar can be used as a soil amendment that has been reported to improve soil water and nutrient retention, soil surface area, earthworm and beneficial microorganism population (Bhuvaneshwari et al., 2019).

\section{Benefits of biochar to the soil}

As a soil amendment, biochar alters the soil surface area, bulk density, pore distribution and water holding capacity (Mukherjee et al., 2014); adsorb both organic and inorganic contaminants and reduce nutrient leaching (Novaket al., 2009). It serves as a slowreleasing reservoir of nutrients in the soil
(Hossain et al., 2011). The combined application of biochar and compost had reported increased activities of $\beta$-glucosidase, FDA hydrolysis and doubled activities of soil alkali phosphatase, protease, and enzymes involved in carbon, nitrogen and phosphorous cycles. As the soil extracellular enzymes are the proximate agents of organic matter decomposition and nutrient cycling, the increased activities of the above enzymes promote the soil nutrient status (Cao et al., 2017). It was reported that the blended application of biochar, compost and fertilizer increased the soil $\mathrm{N}-\mathrm{NH}_{4}, \mathrm{~N}-\mathrm{NO}_{3}, \mathrm{P}$ and $\mathrm{K}$ to 1.3, 1.8, 1.3, 1.7 folds, respectively (Partey et al., 2014).

\section{Benefits of biochar to the plants}

In general, the biochar application (exclusive or with compost and fertilizers) to the soil showed numerous positive effects on various plant metabolisms through which increased yields in various crops. Such effects of biochar on the plants were illustrated as a review concerning the vegetable crops. The usage of biochar in the vegetable crops is comparably lower and the vantages of biochar can be explored to maximize the growth and yield of vegetable crops.

An increase in the plant available water (PAW) in watermelon (Partey et al., 2014) and cowpea (Pudasainiaet al., 2016) was noticed which was attributed by the improved available soil moisture (ASM) brought in by the biochar application at $25 \mathrm{t} \mathrm{ha}^{-1}$, at a depth of $10 \mathrm{~cm}$. In lettuce, improved leaf traits such as increased number of leaves plant ${ }^{-1}$, length; width and area of leaves were found with combined application of biochar and compost to the unfertilized soil (Trupiano et al., 2017). The total plant biomass increased in cowpea with biochar application at $25 \mathrm{t} \mathrm{ha}^{-1}$ at a depth of $10 \mathrm{~cm}$, which was due to improved tap root growth and uptake of water from fine 
biochar pores (Pudasainiaet al., 2016). Similarly, an increase in the plant dry weight was reported in lettuce with the exclusive application of biochar (Trupiano et al., 2017).

The increased yield with the biochar application in various crops is apparently due to the improved soil fertility and water retention. The superior yield associated with biochar application is reported in many vegetable crops namely Basella, cowpea, cucumber, water spinach, lettuce and watermelon.

The application of biochar and compost resulted in a yield increase in Basella sp. and water spinach by 22.1 and 35.5 per cent, respectively (Vinh et al., 2014). The improvement in yield of cucumber with biochar applied at $5 \mathrm{t} \mathrm{ha}^{-1}$ was associated with improved soil property viz., increased $\mathrm{pH}$, total nitrogen content, organic carbon content and available phosphorous along with higher exchangeable bases $\left(\mathrm{Ca}^{2+}, \mathrm{Mg}^{2+,} \mathrm{K}^{+}, \mathrm{Na}^{+}\right)$, by means of increased vine length, fruit length, number of fruits vine ${ }^{-1}$ (Michael et al., 2017). In lettuce, a positive response on yield by the biochar application was reported as attributed by the enhanced activity of the enzymes involved in carbon, nitrogen and phosphorus cycling (alkaline phosphatase, acid phosphatase, phosphohydrolase, lipaseesterase, chymotrypsin and trypsin) and consequently the increased availability of the same nutrients to the plants (Trupiano et al., 2017).

Besides yield, there are also reports on quality enhancement in vegetables by biochar application. The study on the application of biochar to watermelon grafts revealed increased total soluble solids (TSS) and increased sweetness of the fruits which might be probably due to the improved phosphorous and potassium status of the plants as enhanced by biochar application (Villocino and Quevedo, 2015).

\section{Biochar and beneficial microorganisms}

Biochar is found to benefit the beneficial soil microorganisms by increasing their population and activity. It acts as a refuge for soil microbes, letting them colonize into the pores and offer protection against predators like large protozoans, nematodes, mites and Collembolans (Thies and Rillig, 2009). Besides, biochar can be used as a carrier for biofertilizers which can potentially replace the currently used carriers like peat, lignite, vermiculite and perlite (Saranya et al., 2012). The biochar based biofertilizers are found with increased shelf life and good inoculum potential for different strains of microorganisms (Sun et al., 2016). According to the report of Acikgoz et al., (2018), the biochar applied along with Mycorrhiza resulted in improved plant growth which was attributed to increased plant stem diameter, plant height, fresh and dry weight of Chinese cabbage and nutrient availability.

\section{Biochar and greenhouse gas mitigation}

The biochar is nowadays considered as a robust climate change mitigation tool and expected to sequester carbon and to decrease greenhouse gas emission from soil (Brassard et al., 2016). The principal requisites for a material to sequester carbon are the increased persistence in the soil and resistance to chemical oxidation of biomass to $\mathrm{CO}_{2}$ and reduction to $\mathrm{CH}_{4}$, for which the biochar is a perfect fit. As the biochar is produced by partial combustion, it becomes the pyrogenic carbon or the carbon black, which becomes long term carbon sink with very slow chemical transformation, thus making it an ideal soil amendment for climate change mitigation (Izaurralde et al., 2001). The incorporation of biochar at $30 \mathrm{Kg} \mathrm{ha}^{-1}$ as a soil amendment had been reported with 77-86 per cent of the reduction in $\mathrm{N}_{2} \mathrm{O}$ emission (Jia et al., 2012). 


\section{Potential suggestions and solutions to check stubble burning}

Through this review, it is suggested that the gap between stubble burning - GHG's emission - biochar from crop residue climate change mitigation - biochar's effect on soil nutrient status and plant productivity can be rightly linked and directed towards the wise usage of crop residue for production of biochar (instead of burning) and utilization of the same as soil amendment to mitigate the GHG's and sequester the carbon pollution sources, arose from the stubble burning. Thus, a solution is derived from the problem itself.

The crop stubbles can be removed off the farm by Hay Balers and can be used for biochar production. An existing lacuna is an economically viable technology for large scale production of biochar.

In this context, the biogas produced from agricultural and cattle waste can potentially be used as a source of energy for biochar production. Wang et al., (2013) designed an energy pyrolysis system with a continuous biogas supply system that had been successfully piloted for biochar production from crop residue at the Chinese Academy of Sciences, China. This technology can be adopted with modification for suitability to Indian conditions, for large scale biochar production from stubbles.

The farmers of Punjab and Haryana avail electricity and water at no cost, which thrust them to cultivate rice throughout the year. Perhaps, charging them for the usage of power and water is not politically possible too. In these states, the World Bank runs a scheme named 'Paani Bachao, Paise Kamao', (Save water, Earn money), through which the farmers are rewarded with cash for the amount of water they save. This scheme needs to be scaled up to motivate farmers to cultivate diverse crops, other than rice and wheat.
The concept of Rice BioPark is conceptualized by Prof. M. S. Swaminathan, through which he suggests the transformation of stubbles into various products viz., paper, clipboard, animal feed, etc., coupled with generating income and employment opportunities. The M. S. Swaminathan Research Foundation (MSSRF) had established a Rice BioPark at Nay Pyi Taw, Myanmar, as a part of the IndoMyanmar Friendship project. This concept can be adopted in India to curtail stubble burning and to generate income and employment opportunities.

Zero Budget Natural Farming is a technique that employs decreased use of financial and natural resources while increasing the crop yield. Biochar is a boon for the farmers lacking knowledge on farming technology and who cannot afford the cost of fertilizers and other inputs.

Moreover, biochar is found useful for the reclamation of areas with pollution, soil erosion and low productivity. The biochar, thus, can be used as a component in zero budget natural farming to reduce high-cost chemical inputs while maximizing the yield.

The stubble burning is not only an issue of Northern India but also jeopardy of the entire nation, as the resultant air pollution spreads to East, Central and South Inia as well.

The fine black carbon particles disperse from Punjab and Haryana to the Eastern IndoGangetic plains, extending to the states Maharashtra, Chhattisgarh, Odisha and Telangana (Sarkar et al., 2018).

Thus, stubble burning is an act that is essential to be checked, for which the Government support is necessarily required. The biochar from crop residue will serve the purpose of stopping stubble burning and redressing the impact created by the stubble burning. To bring into reality the suggestion of Prof. M. S. 
Swaminathan stating that the stubble should become an income, rather than eco-disaster, the biochar from crop residue is an optimal option.

\section{References}

Acikgoz, F.E., S. Adiloglu, F.I. Yilmaz and Adiloglu. A. 2018. The effects of hazelnut biochar and mycorrhiza applications on some biological characteristics of Pak Choi (Brassica rapa L. subsp. chinensis L.) plant. Proc. IX International Congress on Hazelnut, ActaHortic. 1226. DOI: 10.17660/ActaHortic.2018.1226.43.

Amonette, J. and Joseph, S. 2009. Characteristics of biochar: Micro-chemical properties. In Biochar for Environmental Management: Science and Technology (Eds) Lehmann, J., Joseph, S., Earth Scan: London, UK, Pp. 33-52.

Bhuvanesheari, S., H. Hettiarachchiand Meegoda, J.N. 2019. Crop residue burning in India: policy challenges and potential solutions. Int. J. Environ. Res. Public Health, 16, 832; DOI:10.3390/ijerph16050832.

Brassard, P., S. Godbour and Raghavan, V. 2016. Soil biochar amendment as a climate change mitigation tool: Key parameters and mechanisms involved. Journal of Environmental Management 181, 484497, 484e497.

Cao, Y., Y. Ma, D. Guo, Q. Wang and Wang, G. 2017. Chemical properties and microbial responses to biochar and compost amendments in the soil under continuous watermelon cropping. Plant Soil Environ. 63(1): 1-7, DOI: 10.17221/141/2016-PSE.

Cheng C. H., J. Lehmann, J.E. Thies and Burton, S.D. 2008. Stability of black carbon in soils across a climatic gradient. J. Geophys. Res-Biogeo. 113, G02027(110).

Hossain, M.K., V. Strezov, K.Y. Chan, A. Ziolkowski, Nelson, P.F., 2011. Influence of pyrolysis temperature on production and nutrient properties of wastewater sludge biochar. J. Environ. Manag. 92, $223 \mathrm{e} 228$.
Izaurralde, R.C.. N.J. Rosenberg and Lal, R. 2001. Mitigation of climate change by soil carbon sequestration: Issues of science, monitoring, and degraded lands. Adv. Agron. 70, 1-75.

Jain, N. A. Bhatia and Pathak, H. 2014. Emission of Air Pollutants from Crop Residue Burning in India. Aerosol Air Qual. Res. 14, 422-430.

Jha P., A.K. Biswas, B.L. Lakaria and Rao, A.S. 2010. Biochar in agriculture-prospects and related implications. Curr. Sci. India 99, 1218-1225.

Jia, J., B. Li, Z. Chen, Z. XieandXiong, Z. 2012. Effects of biochar application on vegetable production and emissions of $\mathrm{N}_{2} \mathrm{O}$ and $\mathrm{CH}_{4}$. Soil Scince and Plant Nutrition, 58, 503509, DOI: $10.1080 / 00380768.2012$. 686436.

Jitendra. 2017. India's Burning Issues of Crop Burning Takes a New Turn, Down to Earth. Retrieved from https://www.downtoearth.org.in/coverage/ river-of-fire-57924.

Pudasainia, K., K.B. Walsh, N. Ashwath and Bhattarai, T. 2016. Effects of biochar addition on plant available water of a loamy sandy soil and consequences on cowpea growth. XXIX IHC - Proc. Int. Symp. on Water, Eco-Efficiency and Transformation of Organic Waste in Horticultural Production, ActaHortic. 1112, DOI: 10.17660/ActaHortic.2016. 1112.48 .

Liu, L., G. Shen, M. Sun, X. Cao, G. Shang and Chen, P., 2014. Effect of biochar on nitrous oxide emission and its potential mechanisms. J. Air Waste Manag. Assoc. 64(8): 894e902.

Micheal. O.K., D.A. Ogbujor and Oghenerho, E.A. 2017. Effect of biochar on soil properties and yield of cucumber (Cucumis sativus L.). Int. J. Soil. Sci. Agron., 4(4): 131-142. Mukherjee, A., R. Lal and Zimmerman, A.R., 2014. Effects of biochar and other amendments on the physical properties and greenhouse gas emissions of an artificially degraded soil. Sci. Total Environ. 487, 26e36.

National Policy for Management of Crop Residues (NPMCR). 2014. Department of 
Agriculture and Cooperation (Natural Resource Management Division), Ministry of Agriculture, Government of India. Retrieved from http://agricoop.nic.in/sites/ default/files/NPMCR_1.pdf.

Novak, J.M., I. Lima, B. Xing, J.W Gaskin, C. Steiner, K.C. Das, M. Ahmedna, D. Rehrah, D.W. Watts, W.J. Busscher and Schomberg, H., 2009. Characterization of designer biochar produced at different temperatures and their effect on a loamy sand. Ann. Environ. Sci. 3, 195e206.

Partey S.T., R.F. Preziosiand Robson G.D. 2014. Short-term interactive effects of biochar, green manure, and inorganic fertilizer on soil properties and agronomic characteristics of maize. Agricultural Research, 3, 128-136.

Saranya K., P.S. Krishnan, K. Kumutha and French, J. 2011. Potential for biochar as an alternate carrier to lignite for the preparation of biofertilizers in India. Int. J. Agric. Environ. Biotech. 4, 167-172.

Sarkar. S., R.P. Singh and Chauhan, A. 2018. Crop residue burning in northern India: Increasing threat to greater India. J. Geophys. Res. DOI: 10.1029/2018JD028428.

Satyendra, T. 2015. Impact of Crop Residue Burning on Climate Change: A Scenario of Madhya Pradesh, India. Res. J. Recent. Sci., 4, 94-96.

Spokas K., J. Baker and Reicosky, D. 2010. Ethylene: potential key for biochar amendment impacts. Plant Soil 333: 443452.
Sun D., L. Hale and Crowley, D. 2016. Nutrient supplementation of pinewood biochar for use as a bacterial inoculum carrier. Biol. Fertil Soils 52, 515-522.

Thies J.E. and Rillig, M. 2009. Characteristics of biochar: biological properties. In: Biochar for environmental management: science and technology (eds) Lehmann J. and S. Joseph Earthscan, London., Pp. 85-105

Trupiano, D., C. Cocozza, S. Baronti, C. Amendola, F.P. Vaccari, G. Lustrato, S. Di Lonardo, F. Fantasma, R. Tognettiand Scippa, G.B. 2017. The Effects of Biochar and Its Combination with Compost on Lettuce (Lactuca sativa L.) Growth, Soil Properties, and Soil Microbial Activity and Abundance. International Journal of Agronomy, DOI:10.1155/2017/3158207.

Villocino, S.B. and Quevedo, M.A. 2015. Effects of Biochar on Physicochemical and Sensory Quality of Watermelon (Citrullus lanatus Thunb.) Fruit from Grafted and Non- Grafted Plants. Proc. II Southeast Asia Symp. on Quality Management in Postharvest Systems (Eds) A.L. Acedo Jr. and S. Kanlayanaram. Acta Hort. 1088.

Vinh, N.C., N.V. Hienc, M.L. Anh, J. Lehmann, J and Joseph, S. 2014. Biochar treatment and its effects on rice and vegetable yields in mountainous areas of Northern Vietnam. Int. Inv. J. Agric. Soil Sci., 2(1): 5-13.

Wang, S., X. Zhao, G. Xing and Yang, L. 2013. Large-scale biochar production from crop residue: A new idea and the biogas-energy pyrolysis system. BioResources, 8(1): 811.

\section{How to cite this article:}

Jyothsna, J. 2019. Biochar: An Ingredient to Redress Stubble Burning and Boost Crop Production. Int.J.Curr.Microbiol.App.Sci. 8(12): 20-27.

doi: https://doi.org/10.20546/ijcmas.2019.812.004 